\title{
SIR JOSEPH HOOKER ON INSULAR FLORAS: HUMAN IMPACT AND THE NATURAL LABORATORY PARADIGM
}

\author{
Mark Carine* \& Miguel Menezes de Sequeira*
}

\section{Abstract}

In 1866, the botanist Joseph Dalton Hooker (1817-1911) delivered a lecture to the British Association for the Advancement of Science in Nottingham, U.K. entitled Insular floras. The lecture has been described as "the first systematic statement of the importance of islands for evolutionary studies". As such, it can be seen to have contributed to the development of the "natural laboratory paradigm" that views islands as model systems for studying ecology and evolution. Hooker's lecture also highlighted another key driver in shaping island diversity patterns, namely human impact. How and when does human impact compromise the utility of islands as 'natural laboratories' for studying evolution? To date, no fewer than eight "shortfalls" -knowledge gaps that impact on studies of biodiversity- have been described. In this paper, we suggest that a further shortfall is in order -a Hookerian shortfall- to account for uncertainty in the extent to which biodiversity patterns reflect natural rather than anthropogenic processes.

KEYWORDS: island biogeography, evolution, human impact, herbarium.

\section{LA CONFERENCIA INSULAR FLORAS, DE SIR JOSEPH HOOKER: EL IMPACTO HUMANO Y EL PARADIGMA DEL LABORATORIO NATURAL}

\section{RESUMEN}

En 1866 el botánico Joseph Dalton Hooker (1817-1911) impartió una conferencia a la Sociedad Británica para el Avance de la Ciencia en Nottingham, titulada Floras insulares. Esta conferencia ha sido catalogada como «la primera declaración sistemática de la importancia de las islas para estudios evolutivos». Como tal, puede decirse que contribuyó al desarrollo del concepto de las islas como "paradigma de laboratorio natural», que contempla estas como modelos sistémicos para el estudio de ecología y evolución. La conferencia de Hooker también subrayó la existencia de otro elemento clave en la configuración del patrón de la biodiversidad insular, concretamente, el impacto humano. Cuándo y cómo puede el impacto humano comprometer su utilidad como "laboratorio natural». Hasta el momento se han postulado no menos de ocho carencias, o faltas de conocimiento, que impactan los estudios de biodiversidad. En este trabajo proponemos una nueva carencia, la hookeriana, para considerar la incertidumbre de que los patrones de biodiversidad observados respondan más a procesos naturales que impactos antrópicos.

Palabras Clave: biogeografía insular, evolución, impacto humano, herbario. 


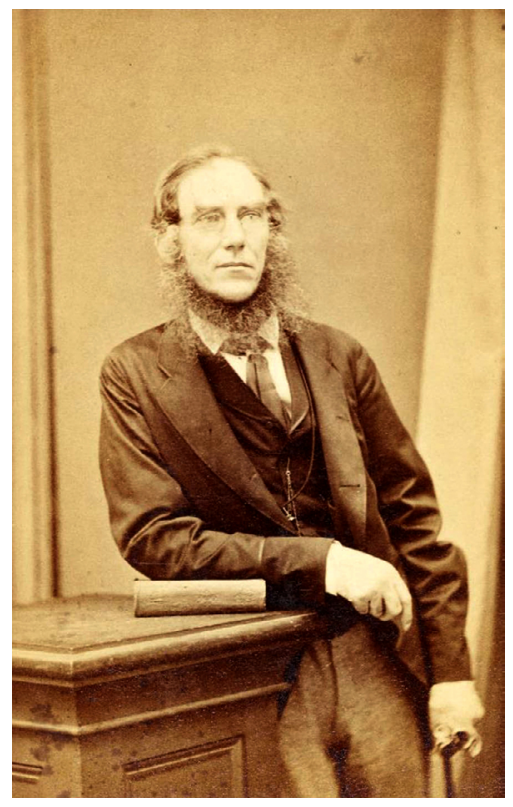

Figure 1. A photograph of Sir Joseph Dalton Hooker (1817-1911), taken in 1868, two years after his Insular Floras lecture. () The Trustees of the Natural History Museum, London.

\section{INTRODUCTION}

On August 27 $7^{\text {th }}$ 1866, Joseph Dalton Hooker (1817-1911; Figure 1), then Director of the Royal Botanic Gardens, Kew in London, U.K., delivered a lecture to the British Association for the Advancement of Science in Nottingham, U.K. His Lecture on Insular Floras (hereafter Insular Floras) was given to an estimated audience of 2000 people (Berry 2009). The text of the lecture was subsequently published in parts in the Gardeners Chronicle and later in its entirety as a pamphlet (Hooker 1896, Figure 2). It was reprinted with a commentary by Williamson (1984). Berry (2009), in reviewing Hooker's contribution to island biology, considered the 1866 Insular Floras lecture to be particularly significant describing it as a '...landmark in

* Algae, Fungi and Plants Division, Department of Life Sciences, The Natural History Museum, United Kingdom. Corresponding author: m.carine@nhm.ac.uk.

** Madeira Botanical Group, Faculty of Life Sciences, University of Madeira, Funchal-Portugal. InBio, Research Network in Biodiversity and Evolutionary Biology, CIBIO-Azores, Portugal. 
DELIVERED BEFORE THE BRITISH ASSOCIATION

FOR THE ADVANCEMENT OF SCIENCE AT

NOTTINGHAM, AUGUST 27, 1866

SIR J. D. HOOKER, C.B., K.C.S.I. M.D., D.C.L., LL.D., F.R.S, F.L.S., SE, LATE DDRECTOK OF THE ROYAL GARDENS, KEW

\section{密}

LON DOS

L. REEVE AND CO

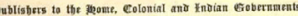

- HENRIETTA sTREET, COVENT GARDEN, W.c,

1896

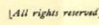

Figure 2. Title page of Hooker's Lecture on Insular Floras, published in its entirety as a 36 page booklet by L. Reeve \& Co. (C) The Trustees of the Natural History Museum, London.

scientific support for the Origin... [i.e. Darwin 1859]' and '...the first systematic statement of the importance of islands for evolutionary studies.'

Hooker's lecture addressed the relationships and evolution of island floras and also considered the extent of human impact on islands and its significance. In this paper we give an overview of Hooker's lecture before considering how these two aspects of island floras he discussed -their role as 'natural laboratories' for studying evolution on the one hand and their highly disturbed condition on the othercan be reconciled.

\subsection{HOOKER AND ISLANDS}

Hooker was an influential figure in $19^{\text {th }}$ century botany. By the time he delivered his Insular Floras lecture he had succeeded his father William Jackson Hooker as the second Director of the Royal Botanic Gardens, Kew, a post he held for 20 years. He served as President of the Royal Society of London, the United Kingdom's premier scientific academy, from 1873 to 1878 . He received a knighthood for his work in India and was made a member of the Order of Merit, an award in the personal gift of the British sovereign. Hooker maintained an extensive and inter- 
national network of correspondents (Endersby 2008a; see also http://jdhooker.kew. $\mathrm{org} / \mathrm{p} / \mathrm{jdh}$ ) and his botanical interests were wide ranging. Eminent in both palaeoand neobotany, Hooker was a prolific collector and explorer and the author and editor of monumental taxonomic works including the seven-volume Flora of British India (Hooker 1872-1897) and Genera Plantarum (Bentham and Hooker 18621883). He was also an advocate of the evolutionary theory developed by his friend Charles Darwin. Hooker considered himself to be a 'philosophical botanist' and was concerned not only with documenting patterns of diversity but also explaining them (Endersby 2008a and b).

Hooker's Insular Floras lecture reflected his particular interest and wide experience of oceanic island floras. As a young Assistant Surgeon in the British Royal Navy, Hooker served on HMS Erebus under James Clarke Ross on the 18391843 Antarctic expedition to the magnetic South Pole. The voyage took Hooker to islands in Macaronesia (Madeira, Tenerife in the Canary Islands and Santiago in the Cabo Verde), the South Atlantic (the São Pedro and São Paulo rocks, Trindade, Ascension, Saint Helena, the Falkland Islands) and the sub-Antarctic and Antarctic (Auckland, Crozet, Kerguelen, Cockburn and Campbell islands). He used the opportunity to collect extensively; everything from algae to seed plants. In writing up the botanical outcomes of the Erebus voyage, Hooker produced Floras of New Zealand, the Antarctic islands and Tasmania (Hooker 1844-1860) but his interests in island floras extended beyond those he had visited on the voyage; his Enumeration of the Plants of the Galapagos Archipelago (Hooker 1847) for example, was made at the invitation of Charles Darwin and was based on Darwin's collections from the archipelago. It was a project that established a life long friendship between the two men.

\subsection{EXPLAINING INSULAR FLORAS}

Hooker's Insular floras lecture provided an outline of the physical characteristics and floras of seven oceanic islands or island groups. He discussed the Macaronesian archipelagos of the Azores, Madeira, Canary Islands and the Cabo Verde, the south Atlantic islands of Ascension and Saint Helena and the sub-Antarctic Kerguelen Islands. Hooker had botanized on all except Azores but his interest in the archipelago is evident from surviving correspondence between, for example, Hooker and Darwin (https://www.darwinproject.ac.uk/).

Hooker went on to distinguish two types of relationship of these insular floras: those of affinity and those of analogy. He highlighted analogous similarities in insular floras 'due to physical conditions common to them all - to their climate, exposure, limited area and distance from continents, etc...' noting, for example, the distinctive growth form spectrum of island floras and the phenomenon of insular woodiness, writing that 'Plants which are herbs on continents, often either themselves become shrubby on islets, or are represented by allied species that are shrubby or arboreous'.

His 'relationships of affinity' concerned the biogeographic relationships of insular floras. He noted 'in all cases the flora is quite manifestly closely allied to some 
one continental Flora, and that however distant it may be from the mother continent, and however it by so much approximates to another continent, it never presents more than faint traces of the vegetation of such other continent', a pattern reflected in contemporary phylogenetic analyses of oceanic island seed plant floras (e.g. Carine et al. 2004).

Writing on the Azores in this context, an archipelago located $1700 \mathrm{~km}$ from Europe and $2400 \mathrm{~km}$ from America but with prevailing winds from the West, Hooker noted 'The only trace of American influence on the Azorean Flora that I can substantiate, is in a species of the Umbelliferous genus Sanicula'. Recent phylogenetic work has confirmed the largely European affinity of the endemic seed plant flora and indeed suggests that Sanicula azorica is in fact European in its affinities (H. Schaefer, TUM, pers. comm.). Endemic taxa with American sister taxa are represented, for example in Lactuca (Dias et al. 2018) and Solidago (Schaefer 2015), but they are few in number and Hooker's observations on the flowering plant flora still stand (although the situation is more complex in the cryptogams; see Vanderpoorten et al. 2007).

Hooker reflected on the impact of what would today be considered to be the island life cycle (Whittaker et al. 2007) on levels of diversity. Discussing in particular 'old species', he noted 'I believe that a principal cause of the rarity or extinction of old species on oceanic islands is the subsidence they have all experienced. This sinking of the island operates in various ways. 1. It reduces the number of spots suitable to the habits of the plant. 2. It accelerates that struggle for existence which must terminate in the more hardy or more prolific displacing the less hardy or less prolific...'

He concluded his essay with a discussion of hypotheses to account for the 'stocking of an oceanic island with plants from the continent'. He discussed both dispersal and land bridge hypotheses and carefully assessed the evidence in support of each. Whilst land bridges are no longer considered a plausible hypothesis to explain the origins of oceanic island floras such as those of Macaronesia, it is nevertheless evident in the case of the Macaronesian islands that their 'stocking' has been complex and that their floras contain both neo-endemics, resulting from (relatively) recent dispersal and also palaeoendemics that are the result of continental extinction processes (e.g. Mairal et al. 2015).

Many of the questions that Hooker addressed in his lecture remain central to island biogeographic and evolutionary studies today. His lecture played an important role in highlighting the value of islands as 'natural laboratories'; systems ideally suited for in-situ studies of evolution (Whittaker and Fernández-Palacios 2007) and it is clear that islands continue to play a major role in the development of key concepts in biology (Warren et al. 2015; Santos et al. 2016; Patińo et al. 2017, Whittaker et al. 2017).

\subsection{HOOKER ON HUMAN IMPACT}

Hooker's lecture was not restricted to a presentation of island biogeography and evolution. He also addressed the impact of humans on island floras. 


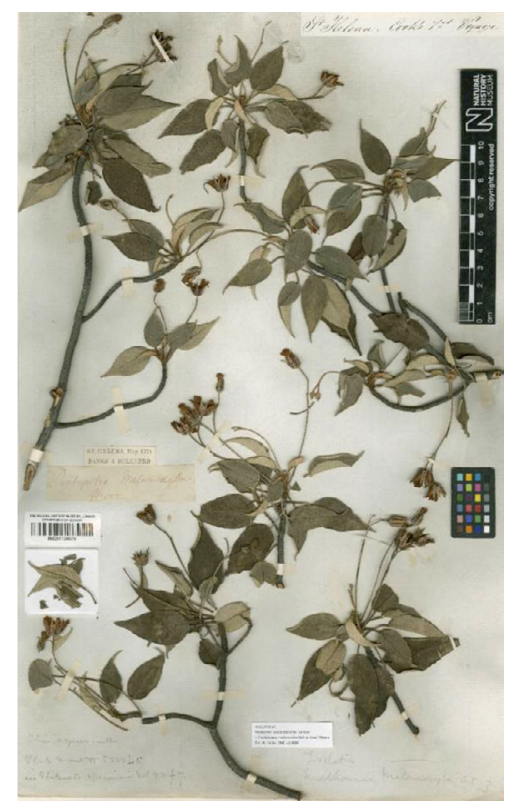

Figure 3. The type specimen of Trochetiopsis melanoxylon collected by Joseph Banks and Daniel Solander on Saint Helena in 1771. The species is endemic to Saint Helena. It is globally extinct and the Banks and Solander type collection made in 1771 was the last collection of the species. There are two other species of Trochetiopsis endemic to Saint Helena: T. erythroxylon is Extinct in the Wild and T. ebenus is Critically Endangered. Image from the Natural History Museum, London data portal (data.nhm.ac.uk), , used under a CC-BY 4.0 licence.

(c) The Trustees of the Natural History Museum, London.

Writing on Saint Helena in the south Atlantic he commented that Probably 100 Saint Helena plants have thus disappeared from the Systema Naturae since the first introduction of goats on the island.'Saint Helena was uninhabited before the $16^{\text {th }}$ century. Goats were introduced as a source of meat in the early 1500 s and, as a result of its strategically important location, the island was colonised and became a major port of call for the British East India Company from the mid-1600s onwards. The introduction of large herbivores and invasive plant species and the harvesting of forests for timber brought about rapid and catastrophic changes to the native vegetation following the discovery and colonisation of the island (Cronk 2000). Hooker's estimate of the scale of species extinction may be an over-estimate but the Saint Helena flora has, undoubtedly, been hugely impacted by humans. Today, it is among the most threatened in the world with one quarter of the 35 recognised endemic flowering plant species considered globally extinct or extinct in the wild (Figure 3). The most recent extinction was of Nesiota elliptica Roxb. When Joseph Banks and Daniel Solander visited the island in 1771 during James Cook's 
first circumnavigation, there were trees up to $9 \mathrm{~m}$ high; a century later only 12-15 trees remained, all much shorter in stature. The last wild plant died in 1994 but seedlings and a cutting propagated from this individual survived until the last succumbed to fungal infections in 2003 (Lambdon and Ellick 2016). Cronk (2016) used the Nesiota example to illustrate the sometimes long period of time taken for extinction to occur following an extinction-causing event and to highlight the need to focus on estimating extinction debt (see also, for example, Triantis et al. 2010, Otto et al. 2017 in the context of Macaronesia) rather than census extinction if we are to understand the true scale of biodiversity loss.

Hooker also drew attention to the impact of humans on the Madeiran flora. He commented 'But in Madeira the agency of man must not be overlooked. The natural history of that lovely island has undergone such a revolution within the last 400 years, as under the ordinary operations of Nature can only be measured by the Geological Chronometer'.

This statement is at odds with the idea that the extensive areas of Madeiran laurisilva are largely primary forest (e.g. http://whc.unesco.org/en/list/934) but it is certainly consistent with historical data. Early descriptions of Madeira (and also the Azores) refer to large forests comprising some species still present in the region but others that are unknown and are probably extinct (Frutuoso 1998; Dias 2007). Early reports also document the rapid destruction of forest ecosystems in the $15^{\text {th }}$ (e.g. Fernandes 1940) and $16^{\text {th }}$ centuries (Gaspar Frutuoso; see Frutuoso 1998). Moore $(2009,2010)$ estimated that the development of massive sugar cane plantations and forest cutting for fuel to produce sugar from the $15^{\text {th }}$ century onwards resulted in close to 16,000 ha of forest being cut by 1509; a less optimistic estimate would put that figure close to 25,000 ha. That corresponds to between one quarter and $40 \%$ of the total area of laurisilva destroyed by the early $16^{\text {th }}$ century.

Evidence for the lack of forest or for a landscape converted to agriculture can also be found in the writings of $17^{\text {th }}$ and $18^{\text {th }}$ century authors such as Hans Sloane (Menezes de Sequeira et al. 2010). Later, the influence of Alexander von Humboldt led authors such as Bowdish (1825), Khul (1826) and Lowe (1857) to propose vegetation belts for Madeira that were largely based on the distribution of cultivated plants and landscapes intensively used for grazing. Nineteenth century images (Pupo-Correia et al. 2010) reveal a barren landscape largely used for agriculture and heavily grazed where tall trees could seldom be found and, where they did occur, they were usually linked to villages or houses (Figure 4).

Recent research has revealed that even the oldest forest stands in Madeira show signs of historical harvesting dating back to about 150 years ago (Patiño et al. 2018). The recovery of the laurisilva in Madeira was therefore a late and recent process that took place mostly in the $20^{\text {th }}$ century. Madeiran laurisilva today is thus likely to be much more extensive than it was in the relatively recent past. Hooker's view of the laurisilva during his visit aboard the Erebus would have been very different to that of a visitor today and inferences regarding its composition and evolution that would have been made in the early 1800 s may have been very different to those made today if the history of the forests is not taken into account. 

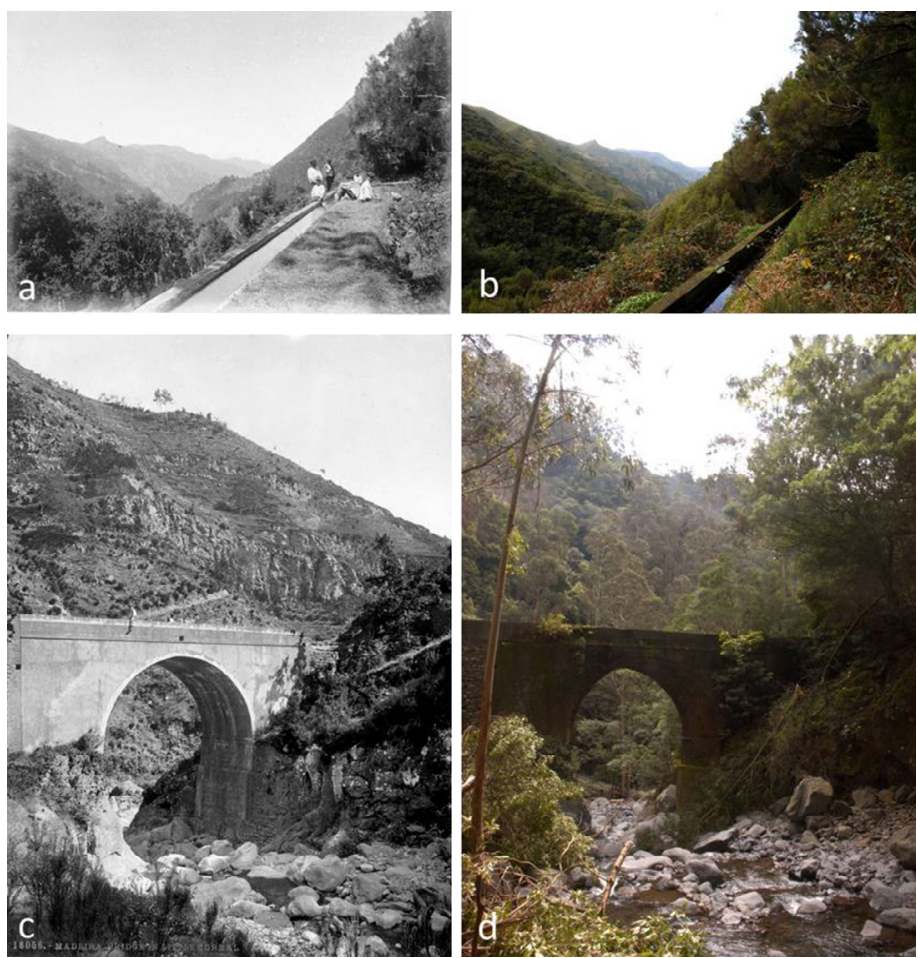

Figure 4. Repeat photography of Madeiran landscapes reveals the different fates of native vegetation through time. (a) and (b): Ribeira da Janela Valley. (a) Photograph taken by unknown photographer in the early $20^{\text {th }}$ century showing large areas without vegetation cover forming clearings in a complex mosaic of forest and scrub. (b) Photograph taken in 2007 showing recovery of native vegetation in areas that were not covered in (a). The transition is to high-scrub or young forest with early secondary, shade intolerant species such as Myrica faya and Clethra arborea. (c) and (d): Old Curral dos Romeiros or Curral pequeno. (c) Photograph taken by unknown photographer between 1876 and 1878 showing the lack of native forest; some native vegetation, mainly heather (Erica platycodon subsp. maderincola), is scattered in the landscape particularly in less accessible areas. The trees are exotic species (e.g. Sycamore (Piatanus $\mathrm{x}$ hispanica) and pine

(Pinus pinaster)). (d). Photograph taken in 2011 showing the increase of tree cover. However, unlike in (b), it is exclusively by exotic trees: Tasmanian Blue Gum (Eucalyptus globulus), Black wattle (Acacia mearnsii) and Sweet Pittosporum (Pittosporum undulatum). Images courtesy of Aida Pupo-Correia.

As the examples of Saint Helena and Madeira serve to highlight, humans have had a profound impact on island floras. Humans have brought about a major loss of island biodiversity but the effects of human activity on island plants is complex. Pressures change through time and the vegetation responds to those changes. Consequently, what is natural and what is human-mediated may actually be extremely difficult to separate. 
Hooker reflected on the significance of human impact for understanding island floras. In the context of Saint Helena he commented that 'Every one of those [extinct species] was a link in the chain of created beings, which contained within itself evidence of the affinities of other species, both living and extinct, but which evidence is irrecoverably lost.'

Contemporary evolutionary and biogeographic analyses on islands range from broad-scale macro-evolutionary or biogeographic analyses to fine-scale analyses of speciation processes and Next Generation Sequencing (NGS) approaches have the potential to greatly extend the scope of island evolutionary studies to encompass fundamental questions relating to the genetic basis of island diversification events. The acquisition of DNA sequence data at the genomic level at an ever-increasing rate, and for non-model organisms, is providing unprecedented opportunities to uncover the history of lineages (Sousa and Hey 2013; Ellegren 2014). It is not only allowing evolutionary relationships to be elucidated in rapidly evolving island lineages that were previously intractable (e.g. Mort et al. 2015) but is also allowing the genomic basis of speciation events to be investigated, to determine the number of loci involved in speciation, the nature of the genetic differences, and what those loci control (e.g. Almén et al. 2016; Paun et al. 2015).

But are there limits to our evolutionary inferences in oceanic island systems? Whilst islands have played a significant role as model systems in the development of evolutionary and biogeographic theory, such studies generally assume that the patterns of diversity that they document and that they seek to explain are the result of natural processes with the impact of humans not significant for the interpretation of those patterns. Given the breadth of human impact on islands, is this a reasonable assumption across the entire spectrum of evolutionary questions? Jardim and Menezes de Sequeira (2008) and Menezes de Sequeira et al. (2013) have proposed that forest persistence in Madeira post-human colonization may be linked to the orographic complexity of the island. There is no evidence of any pristine forest in Madeira, but orographic complexity may have prevented the simultaneous disappearance of all forest patches. Conceivably, a dynamic mosaic of mature, although not pristine, forest survived in small and inaccessible areas, resulting in a higher level of conservation in Madeira than in the Azores, as has been observed for arthropods (Boeiro et al. 2018). However, this history certainly challenges the use of contemporary diversity patterns to make biogeographical comparisons between archipelagos. Helmus et al. (2014) demonstrated how human introductions have modified species diversity patterns in Caribbean Anolis lizards whilst Bochaton et al. (2017) showed how human-mediated extinction in Anolis ferreus in Guadeloupe has brought about a marked reduction in its morphological diversity. Seerholm et al. (2018) have drawn attention to the significant loss of genetic diversity in the kakapo on New Zealand as a result of European and pre-European human impact. These examples highlight how past human impact on islands has shaped the diversity patterns observed today on islands across evolutionary scales and how it may impact our interpretation of those patterns. As Whittaker and Fernán- 
dez-Palacios (2007) noted, without understanding the impact of extinction, there is a danger of misinterpreting evolutionary patterns that are just the more resistant fragments of formerly rather different tapestries.

What is not clear is whether, as the focus of studies moves from broad-scale (e.g. the biogeographic relationships of island biota) to finer-scale questions (e.g. speciation genomics), anthropogenic rather than natural processes become increasingly significant in explaining the patterns we observe. Is there a critical point below which anthropogenic effects are so significant that robust inferences concerning natural, ecological and evolutionary processes are simply not possible? Is there a limit to the use of islands as 'natural laboratories' for studying evolution?

\subsection{A HOOKERIAN SHORTFALL?}

Shortfalls in our knowledge of the diversity of island floras have been discussed by a number of authors. For example, Schaefer et al. (2011) discussed the significance of a Linnean shortfall (Brown and Lomolino 1998) -the incomplete knowledge of taxonomic diversity- in understanding and explaining patterns of diversity in the flora of the Azores. The Linnean shortfall, together with the Wallacean shortfall (Lomolino 2004) -the incomplete knowledge of taxon distributionswere first proposed in the context of conservation biology.

Further shortfalls in biodiversity knowledge have now been identified. Cardoso et al. (2011) proposed a Prestonian shortfall to account for the deficiency in knowledge of species abundance and population dynamics whilst Diniz-Filho (2013) proposed a Darwinian shortfall to account for lack of knowledge of the tree of life. Hortal et al. (2015) further extended the concept of shortfalls and proposed in addition three further shortfalls: the Raunkierian (lack of knowledge of species traits and their functions), Hutchinsonian (lack of knowledge about the responses and tolerances of species to abiotic conditions) and the Eltonian (lack of knowledge of species interactions and their effects on survival and fitness). Ficetola et al. (2018) recently proposed the Racovitzan impediment for our lack of knowledge of the biodiversity of unexplored environments.

Conspicuous by its absence from this list is the shortfall discussed here -the shortfall in our knowledge of the extent to which patterns of biodiversity are shaped by anthropogenic rather than natural processes- a shortfall that might be termed the 'Hookerian shortfall'. As is clear from his Insular floras lecture, Hooker was aware of this problem and he was, arguably, the first to articulate it.

In the context of island conservation, Nogué et al. (2017) have highlighted the importance of palaeoecological studies in establishing baselines. Paleoecological baselines could help to inform island evolutionary studies and address the 'Hookerian shortfall'. Historical accounts that bear direct testimony of human impact written by those who were witnesses to it may also be informative although they are often limited by poor taxonomic resolution.

Herbarium collections provide another source of data to help understand the 'Hookerian shortfall'. The world's herbaria contain an estimated 350 million bota- 
nical specimens (Thiers 2016) collected over more than four hundred years. NGS techniques have not only greatly extended the potential scope of island evolutionary studies to encompass fundamental questions relating to the genetic basis of island diversification events but they have also expanded the range of material that may be used in studies of island biodiversity to include for example, archival herbarium specimens or wood samples that were difficult or impossible to utilise with traditional Sanger sequencing due to the degraded nature of the DNA they contain. Bieker and Martin (2018) recently reviewed the increasing use of archival plant samples in evolutionary and population genetic studies and to examine change over decadal or centennial time scales. For example, Mende and Hundsdoerfer (2013) used museum specimens to demonstrate in a continental setting, how novel patterns of molecular diversity can establish surprisingly quickly. Such changes are unlikely to be tractable using palaeoecological or, indeed historical textual analyses but may be tractable using archival samples.

Herbarium specimens are thus a potential source of data to test the robustness of diversity patterns and the processes inferred from those patterns through the last 400 years -a period of profound anthropogenic change- and the Atlantic islands may be particularly amenable to this since their strategic importance for European powers means that there has been a long history of collecting.

In the case of Saint Helena, for example, its flora was studied, documented and collected soon after colonisation. The oldest surviving collections were made by Stonestreet in 1698 and are at the Natural History Museum in London (Dandy 1958); $60 \%$ of the known endemic plant taxa were collected before the $19^{\text {th }}$ century and there is a rich historical record of the flora in herbaria. These early collections provide a record of the endemic flora of an oceanic island soon after its colonisation and a unique resource for understanding the profound changes in the island's flora brought about by human activity. To date, early collections from the island have provided evidence for large-scale range reduction in dominant tree species (Cronk 1986) and have provided evidence for the scale and pace of extinction in the angiosperm flora (Cronk 2000). Herbarium specimens from Saint Helena could be used to investigate how the loss of diversity within endemic species or lineages such as Trochetiopsis (Figure 3) impact on our inferences regarding the evolution of the flora.

Herbarium collections are a far from perfect sample of diversity as they are heavily biased in both space and time. However, they do provide a source of data on the species or lineages or genotypes or genes (depending on the evolutionary scale being addressed) present at a particular place at a particular time. In so doing, they provide a source of data that can be used to help test the robustness of biodiversity patterns through time and help to establish the significance of the Hookerian shortfall in island biogeography. 


\section{CONCLUSIONS}

Hooker's lecture on Insular floras reflected his profound interest in the plant diversity of oceanic islands. It was rooted in his first hand experience of island floras gained through his time as an Assistant Surgeon on James Clarke Ross's Erebus and Terror expedition and his subsequent work on island Floras. It addressed significant questions regarding the assembly and evolution of island biota and the extent of human impact. The extent to which human impact rather than natural processes explain the diversity patterns observed on islands and how this varies across evolutionary scales remains poorly understood. We propose here that we should recognise this shortfall in our understanding of island diversity as the 'Hookerian shortfall'.

Hooker's interest in islands was rooted in his work with botanical collections: both the collections he himself made on islands and the collections of others that he used to document island diversity. Those historical collections today provide a potential source of data to help understand the scale of the 'Hookerian shortfall' in island biogeographic and evolutionary studies.

\section{ACKNOWLEDGMENTS}

We are grateful to Aida Pupo-Correia for the photographs used in Figure 4, Hanno Schaefer for insights in the relationships of Sanicula azorica and to two anonymous referees for their constructive comments on this paper.

\section{AUTHORS CONTRIBUTION}

Both authors contributed to the writing of this paper. 


\section{REFERENCES}

Almén, M.S., Lamichhaney, S., Berglund, J., Grant, B.R., Grant, P.R., Webster, M.T. and Andersson, L. 2016. Adaptive radiation of Darwin's finches revisited using whole genome sequencing. BioEssays 38: 14-20.

Bentham, G. and Hooker, J.D. 1862-1883. Genera Plantarum. 3 vols. London: L. Reeve \& Co. $1484 \mathrm{pp}$.

Berry, R.J. 2009. Hooker and islands. Biol. J. Linn. Soc. 96: 462-481.

Bieker, V.C. and Martin, M.D. 2018. Implications and future prospects for evolutionary analyses of DNA in historical herbarium collections. Bot. Lett. 165: 409-418.

Bochaton, C., Bailon, S., Herrel, A., Grouard, S., Ineich, I., Tresset, A. and Cornette, R. 2017. Human impacts reduce morphological diversity in an insular species of lizard. Proc. R. Soc. B 284: 20170921.

Boieiro, M., Matthews, T.J., Rego, C., Crespo, L., Aguiar, C.A.S., Cardoso, P., Rigal, F. Silva, I., Pereira, F., Borges, P.A.V. and Serrano, A.R.M. 2018. A comparative analysis of terrestrial arthropod assemblages from a relict forest unveils historical extinctions and colonization differences between two oceanic islands. PLOS One, 13: e0195492.

Bowdich, S. 1825. Excursion in Madeira and Porto Santo, during the autumn of 1823, while on his third voyage to Africa by the late T. Edward Bowdich. London: George B. Whittaker 278 pp.

Brown, J.H. and Lomolino, M.V. 1998. Biogeography ( $2^{\text {nd }}$ ed.). Sunderland: Sinauer 691 pp.

Cardoso, P., Erwin, T.L., Borges, P.A. and New, T.R. 2011. The seven impediments in invertebrate conservation and how to overcome them. Biol. Cons. 144: 2647-2655.

Carine, M.A., Francisco-Ortega, J., Santos-Guerra, A. and Russell, S.J. 2004. Relationships of island and continental floras: molecular evidence for multiple colonisations into Macaronesia and subsequent back-colonisation of the continent in Convolvulus L. Am. J. Bot. 91: 1070-1085.

Cronk, Q.C.B. 1986. The decline of the Saint Helena ebony Trochetiopsis melanoxylon. Biol. Cons. 35: $159-172$.

Cronk, Q.C.B. 2000. The endemic flora of Saint Helena. Oswestry: A. Nelson 119 pp.

Cronk, Q.C.B. 2016. Plant extinctions take time. Science 353: 446-447.

DANDY, J.E. 1958. The Sloane Herbarium: an annotated list of the Horti Sicci composing it, with biographical accounts of the principal contributors. London: Trustees of the British Museum $246 \mathrm{pp}$.

DARWIN, C. 1859. On the origin of species by means of natural selection. London: John Murray 502 pp.

Dias, E.F., Kilian, N., Silva, L., Schaefer, H., Carine, M., Rudall, P.J., Santos-Guerra, A. and Moura, M. 2018. Phylogeography of the Macaronesian lettuce species Lactuca watsoniana and L. palmensis (Asteraceae). Biochem. Gen., 56: 315-340.

Diss, E. 2007. A Chegada dos portugueses às ilhas -o antes e o depois- Açores. In: Silva, J. (ed.). Arvores e Florestas de Portugal. Volume 6, Açores e Madeira - A Floresta das Ilhas. Público, Comunicação Social SA, Fundaçáo Luso Americana para o Desenvolvimento e Liga para a Protecção da Natureza, pp. 135-164.

Diniz-Filho, J.A.F., Loyola, R.D., Raia, P., Mooers, A.O. and Bini, L.M. 2013. Darwinian shortfalls in biodiversity conservation. Trends Ecol. Evol. 28: 689-695. 
Ellegren, H. 2014. Genome sequencing and population genomics in non-model organisms. Trends Ecol. Evol. 29: 51-63.

Endersby, J. 2008a. Imperial nature: Joseph Hooker and the practices of Victorian science. Chicago: University of Chicago Press 429 pp.

Endersby, J. 2008b. Joseph Hooker: a philosophical botanist. J. Biosci. 33: 163-169.

Fernandes, V. 1940. Manuscrito (O) de Valentim Fernandes. Leitura e Revisão de Provas por António Baião. Lisboa: Academia Portuguesa de História 240 pp.

Ficetola, G.F., Canedoli, C. and Stoch, F. 2019. The Racovitzan impediment and the hidden biodiversity of unexplored environments. Cons. Biol. 33: 214-216.

Frutuoso, G. 1998. Saudades da terra: livro II. Nova ed. Ponta Delgada: Instituto Cultural de Ponta Delgada 473 pp.

Helmus, M.R., Mahler, D.L. and Losos, J.B. 2014. Island biogeography of the Anthropocene. Nature 513: 543-546.

Hooker, J.D. 1844-1860. The botany of the Antarctic voyage of HM discovery ships Erebus and Terror in the years 1839-1843: under the command of Captain Sir James Clark Ross. 3 vols. London: L. Reeve and Co. 422 pp.

Hooker, J.D. 1847. An Enumeration of the Plants of the Galapagos Archipelago; with Descriptions of those which are new. Trans. Linn. Soc. London 20: 163-233.

Hooker, J.D. 1872-1897. Flora of British India. 7 vols. London: L. Reeve \& Co. Ltd. 856 pp.

Hooker, J.D. 1896. Lecture on Insular Floras. London: L. Reeve \& Co. 36 pp.

Hortal, J., De Bello, F., Diniz-Filho, J.A.F., Lewinsohn, T.M., Lobo, J.M. and Ladle, R.J. 2015. Seven shortfalls that beset large-scale knowledge of biodiversity. Ann. Rev. Ecol. Evol. Syst. 46: 523-549.

Jardim, R. and Menezes de Sequeira, M. 2008. As Plantas Vasculares (Pteridophyta e Spermatophyta) dos Arquipélagos da Madeira e das Selvagens. In: Borges, P.A.V., Abreu, C., Aguiar, A.M.F., Carvalho, P., Jardim, R., Melo, I., Oliveira, P., Sérgio, C., Serrano, A.R.M. and Vieira, P. (eds.). A list of the terrestrial fungi, flora and fauna of Madeira and Selvagens archipelagos. Funchal and Angra do Heroísmo: Direcção Regional do Ambiente da Madeira and Universidade dos Açores, .

Khul, H. 1826. On the Vegetable Productions of the Island of Madeira. Edin. J. Sci. 4: 119-124.

Lambdon, P.W. and Ellick, S. 2016. Nesiota elliptica. The IUCN Red List of Threatened Species 2016: e.T37598A67372241. [Accessed 05 Feb 2019]. Available from: http://dx.doi. org/10.2305/IUCN.UK.2016-1.RLTS.T37598A67372241.en.

Lomolino, M.V. 2004. Conservation biogeography. In: Lomolino M.V. and Heaney L.R. (editors). Frontiers of Biogeography: New Directions in the Geography of Nature. Sunderland: Sinauer, pp. 293-296.

Lowe, R.T. 1957. Manual Flora of Madeira and the adjacent islands of Porto Santo and the Desertas. Vol. I, part. 1. London: John van Voorst.

Mairal, M., Pokorny, L., Aldasoro, J.J., Alcarón, M. and Sanmartín, I. 2015. Ancient vicariance and climate-driven extinction explain continental-wide disjunctions in Africa: the case of the Rand Flora genus Canarina (Campanulaceae). Mol. Ecol. 24: 1335-1354. 
Mende, M.B. and Hundsdoerfer, A.K. 2013. Mitochondrial lineage sorting in action-historical biogeography of the Hyles euphorbiae complex (Sphingidae, Lepidoptera) in Italy. BMC Evol. Biol. 13: 83.

Menezes de Sequeira, M., Capelo, J., Jardim, R. and Pupo, A. 2013. Comments on the Vascular Flora of Madeira: History, recent advances and relations with other Macaronesian archipelagos. In: Caujapé-Castells, J., Nieto Feliner, G. and Fernández-Palacios, J.M. (eds.) Proceedings of the Amurga international conferences on island biodiversity 2011. Las Palmas de Gran Canaria: Fundación Canaria Amurga-Maspalomas, , pp. 228-236.Menezes DE Sequeira, M., Jardim, R. and Capelo, J. 2007. A Chegada dos portugueses às ilhas - o antes e o depois - Madeira. In: Silva, J. (ed). Árvores e Florestas de Portugal. Volume 6, Açores e Madeira - A Floresta das Ilhas. Público, Comunicação Social SA, Fundação Luso Americana para o Desenvolvimento e Liga para a Protecção da Natureza, pp. 165-196.

Menezes de Sequeira, M., Santos-Guerra, A., Jarvis, C.E., Oberli, A., Carine, M.A., Maunder, M. and Francisco-Ortega, J. 2010. The Madeiran plants collected by Sir Hans Sloane in 1687, and his descriptions. Taxon 59: 598-612.

Moore, J.W. 2009. Madeira, Sugar, and the Conquest of Nature in the "First" Sixteenth Century. Part I: From "Island of Timber" to Sugar Revolution, 1420-1506. Review 32: 345-390.

Moore, J.W. 2010. Madeira, Sugar, and the Conquest of Nature in the "First" Sixteenth Century, Part II: From Regional Crisis to Commodity Frontier, 1506-1530*. Review 33: 1-24.

Mort, M.E., Crawford, D.J., Kelly, J.K., Santos-Guerra, A., Menezes de Sequeira, M., Moura, M. and Caujapé-Castells, J. 2015. Multiplexed-shotgun-genotyping data resolve phylogeny within a very recently derived insular lineage. Am. J. Bot. 102: 634-641.

Nogué, S., De Nascimento, L., Froyd, C.A., Wilmshurst, J.M., De Boer, E.J., Coffey, E.E.D., Whittaker, R.J., Fernández-Palacios, J.M. and Willis, K.J. 2017. Island biodiversity conservation needs palaeoecology. Nature Ecol. Evol. 1: 0181.

Otto, R., Garzón-Machado, V., Del Arco, M., Fernández-Lugo, S., De Nascimento, L., Oromí, P., Báez, M., Ibáñez, M., Alonso, M.R. and Fernández-Palacios, J.M. 2017. Unpaid extinction debts for endemic plants and invertebrates as a legacy of habitat loss on oceanic islands. Divers. Distrib. 23: 1031-1041.

Patiño, J., Whittaker, R.J., Borges, P.A.V., Fernández-Palacios, J.M., Ah-Peng, C., Araújo, M.B., Ávila, S.P., Cardoso, P., Cornuault, J., De Boer, E.J., De Nascimento, L., Gil, A., González-Castro, A., Gruner, D.S., Heleno, R., Hortal, J., Illera, J.C., Kaiser-Bunbury, C.N., Matthews, T.J., Papadopoulou, A., Pettorelli, N., Price, J.P., Santos, A.M., Steinbauer, M.J., Triantis, K.A., Valente, L., Vargas, P., Weigelt, P. and Emerson, B.C. 2017. A roadmap for island biology: 50 fundamental questions after 50 years of The Theory of Island Biogeography. J. Biogeogr. 44: 963-983.

Patiño, J., Gómez-Rodríguez, C., Pupo-Correia, A., Menezes de Sequeira, M. and VanderPOORTEN, A. 2018. Trees as habitat islands: Temporal variation in alpha and beta diversity in epiphytic laurel forest bryophyte communities. J. Biogeogr. 45: 1727-1738.

Paun, O., Turner, B., Trucchi, E., Munzinger, J., Chase, M.W. and Samuel, R. 2015. Processes driving the adaptive radiation of a tropical tree (Diospyros, Ebenaceae) in New Caledonia, a biodiversity hotspot. Syst. Biol. 65: 212-227.

Pupo Correia, A., Aranha, J. and Menezes de Sequeira, M. 2010. Photographs from tourist activity: a source to assess vegetation change using repeat landscape photography. J. Sustain. Tour. 1: 13-17. 
Santos, A.M.C., Field, R. and Ricklefs, R.E. (2016) New Directions in island biogeography. Global Ecol. Biogeog. 25: 751-768.

Schaefer, H., Moura, M., Belo Maciel, M.G., Silva, L., Rumsey, F.J. and Carine, M.A. 2011. The Linnean shortfall in oceanic island biogeography: a case study in the Azores. J. Biogeog. 38: 1345-1355.

Schaefer, H. 2015. On the origin and systematic position of the Azorean goldenrod, Solidago azorica (Asteraceae). Phytotaxa 210: 47-59.

Seersholm, F.V., Cole, T.L., Grealy, A., Rawlence, N.J., Greig, K., Knapp, M., Stat, M., Hansen, A.J., Easton, L.J., Shepherd, L. and Tennyson, A.J. 2018. Subsistence practices, past biodiversity, and anthropogenic impacts revealed by New Zealand-wide ancient DNA survey. Proc. Natl. Acad. Sci. USA. 115: 7771-7776.

Sousa, V. and HeY, J. 2013. Understanding the origin of species with genome-scale data: modelling gene flow. Nat. Rev. Gen. 14: 404-414.

Thiers, B. 2016. Index Herbariorum: A Global Directory of Public Herbaria and Associated Staff. New York Botanical Garden's Virtual Herbarium. Available from http://sweetgum.nybg. org/science/ih/.

Triantis, K.A., Borges, P.A.V., Ladle, R.J., Hortal, J., Cardoso, P., Gaspar, C., Dinis, F., Mendonça, E, Silveira, L.M.A., Gabriel, R., Melo, C., Santos, A.M.C., Amorim, I.R., Ribeiro, S.P., Serrano, A.R.M., Quartau, J.A. and Whittaker, R.J. 2010. Extinction debt on oceanic islands. Ecography 33: 285-294.

Vanderpoorten, A., Rumsey, F.J. and Carine, M.A. 2007. Does Macaronesia exist? Conflicting signal in the bryophyte and pteridophyte floras. Am. J. Bot. 94: 625-639.

Warren, B.H., Simberloff, D., Ricklefs, R.E., Aguilée, R., Condamine, F.L., Gravel, D., Morlon, H., Mouquet, N., Rosindell, J., Casquet, J., Conti, E., Cornuault, J., Fernández-Palacios, J.M., Hengl, T., Norder, S.J., Rijsdijk, K.F., Sanmartín, I., Strasberg, D., Triantis, K.A., Valente, L.M., Whittaker, R.J., Gillespie, R.G., Emerson, B.E. and ThÉBAUD, C. 2015. Islands as model systems in ecology and evolution: prospects fifty years after MacArthur \& Wilson. Ecol. Lett. 18: 200-217.

Whittaker, R.J. and Fernández-Palacios, J.M. 2007. Island biogeography: ecology, evolution, and conservation. Oxford: Oxford University Press 416 pp.

Whittaker, R.J., Ladle, R.J., Araújo, M.B., Fernández-Palacios, J.M., Delgado, J.D. and ArÉvalo, J.R. 2007. The island immaturity-speciation pulse model of island evolution: an alternative to the "diversity begets diversity" model. Ecography 30: 321-327.

Whittaker, R.J., Fernández-Palacios, J.M., Matthews, T.J., Borregaard, M.K. and TrianTIS, K.A. (2017) Island biogeography: Taking the long view of nature's laboratories. Science 357, eaam 8326.

Williamson, M. 1984. Sir Joseph Hooker's lecture on insular floras. Biol. J. Linn. Soc. 22: 55-77. 